\title{
Teachers and the Pledge of Allegiance
}

\author{
Laurie Allen Gallancy $\dagger$
}

\section{INTRODUCTION}

In the 1988 presidential campaign, the news media devoted great attention to Governor Dukakis's veto of a statute requiring public school teachers to recite the Pledge of Allegiance as part of classroom instruction. Dukakis justified his veto on the grounds that the Pledge recitation requirement was unconstitutional, a claim he supported with a Massachusetts Supreme Court advisory opinion to that effect, ${ }^{1}$ and Board of Education v Barnette, ${ }^{2}$ a 1943 Supreme Court case holding that requiring public school students to recite the Pledge violated their right to freedom of expression. ${ }^{3}$

The constitutionality of the teacher Pledge requirement is of more significance than the paucity of lower court decisions on the question may suggest. Within months of George Bush's defeat of Michael Dukakis, public reaction to Texas $v$ Johnson, ${ }^{4}$ the flagburning case, underscored Americans' intolerance of unpatriotic views and, particularly, statements that are less than respectful of the American flag. Meanwhile, a number of states retain statutes providing for Pledge recitation in public schools. ${ }^{5}$

The lower courts that have ruled on the teacher Pledge question have decided in favor of the teacher. ${ }^{6}$ Most have found the

\footnotetext{
$\dagger$ A.B. 1986, Princeton University; J.D. 1990, The University of Chicago.

I Opinions of the Justices to the Governor, 372 Mass 874, 363 NE2d 251 (1977) (advisory opinion).

319 US 624 (1943).

3 For a contemporary account (and critique), see Walter Berns, Dukakis' Pledge Is Not to the Law, NY Times § 1 at 27 (Sept 10, 1988).

- 109 S Ct 2533 (1989). The controversy over flag-burning has continued. Following a Supreme Court decision striking down a federal flag-desecration statute, United States $v$ Eichman. 1990 US LEXIS 3087, a vote in the House of Representatives fell only 34 short of the two-thirds majority required to approve a constitutional amendment authorizing flagdesecration laws. Steve Daley and Elaine S. Povich, Democrats Hand Bush Big Defeat, Chicago Tribune $\S 1$ at 1 (June 22, 1990).

- See, for example, Mass Ann Laws ch 71, 69 (Michie/Law Co-op 1978); 14 Del Code Ann $\S$ 4105, 4106 (1981); and Fla Stat $\S 233.065$ (West 1989).

- Only four cases have specifically decided the issue. See Hanover $v$ Northrup, 325 F Supp 170 (D Conn 1970); State v Lundquist, 262 Md 534, 278 A2d 263 (Ct App 1971); Russo v Central School Dist. No. 1, 469 F2d 623 (2d Cir 1972); and Opinions of the Justices to the Governor, 372 Mass 874. Compare Palmer v Board of Education of City of Chicago,
} 
requirement unconstitutional on very narrow grounds, citing a number of facts as relevant to their decisions and thus providing little protection for teachers or guidance for school officials. On the other hand, some of the courts support their holdings with very sweeping statements, often on "schoolhouse" freedom of expression. ${ }^{7}$ The Supreme Court cases cited in support of such a freedom are certainly relevant, but they cannot be applied.mechanically for the same reason that Barnette cannot be: they are, for the most part, about the First Amendment rights of students in the schools. As a result, the reasoning of some of the lower court cases provides no basis for distinguishing between, for example, a requirement placed upon a teacher to recite the Pledge, and a requirement that she follow the curricular choices of school authorities. Such analytical difficulties illustrate that the teacher Pledge requirement issue lies at the intersection of several First Amendment doctrines. Resolving the Pledge question requires exploring ambiguities that arise when these doctrines are superimposed upon one another, and formulating a test that incorporates the most important policies from each area.

The first section of this Comment. shows that Barnette, while highly relevant, cannot control the question of whether forcing teachers to recite the Pledge in class is constitutional, because teachers are public employees. Section II introduces Supreme Court doctrine on public employee speech as the basic structural framework for resolving the Pledge issue. Since the public employee cases also provide an incomplete test for this issue, however, Section III discusses the implications of First Amendment jurisprudence in other areas-compelled speech, loyalty oaths, and speech rights in public schools. Finally, this Comment concludes that forcing a public school teacher to recite the Pledge-that is, compelling her to assert as true a statement of political conviction-is unconstitutional.

466 F Supp 600, 604 (N D Ill 1979) (expressly avoiding the question whether a kindergarten teacher could be discharged for refusal to recite the Pledge, relying instead on her refusal to engage in other holiday activities specified in the curriculum-such as classroom decoration-to justify her dismissal), aff'd, 603 F2d 1271, 1272, 1274 (7th Cir 1979) (characterizing the teacher's refusal to perform a number of civic education duties as an unprotected disregard for "prescribed curriculum").

7 See, for example, Hanover, $325 \mathrm{~F}$ Supp at 172-73. 


\section{The Implications of Barnette}

\section{A. The Meaning of Barnette}

In Board of Education v Barnette, the Court unambiguously held that requiring public school students to recite the Pledge of Allegiance violated the students' First Amendment rights. In Barnette, Jehovah's Witness children and parents attacked a local school board resolution (authorized by state statute) that required public school students to recite the Pledge and salute the flag. ${ }^{8}$ The purpose of the statute, which also provided for instruction in history, civics, and the state and federal constitutions, was avowedly to teach, foster, and perpetuate the "ideals, principles and spirit of Americanism" and to increase knowledge of government. ${ }^{\theta}$ The students, who were subject to expulsion and delinquency proceedings if they failed to say the Pledge, and their parents, who were subject to criminal sanctions if their children were thus expelled, claimed that the statute and regulations violated their First Amendment rights to freedom of religion and freedom of expression.

The Court struck down the regulation as violating the constitutional right to freedom of expression guaranteed by the First Amendment. ${ }^{10}$ The Court began by enunciating what is now known as the "forced (or compelled) speech" doctrine, declaring that the constitutionally-guaranteed freedom of speech encompassed a freedom not to speak, a freedom to be silent. In fact, the Court twice suggested, compelled affirmation could perhaps be commanded only on grounds more urgent than those required to justify sup-

- The words of the Pledge were: "I pledge allegiance to the Flag of the United States of America and to the Republic for which it stands; one Nation, indivisible, with liberty and justice for all." Barnette, 319 US at 628-29. Note that this version did not contain the words "under God." See 36 USC § 172 (1988).

- Barnette, 319 US at 625 .

10 "Congress shall make no law . . . abridging the freedom of speech ...." US Const, Amend I. Some have suggested that the religious basis of the students' objection was the real key to the Court's holding in Barnette, and that the case does not shield all those who might object, for whatever reason, to reciting the Pledge. See Lundquist, 278 A2d at 276-82 (Barnes dissenting); and Palmer, 466 F Supp at 603. However, the Barnette plurality opinion is quite clear that "the issue [does not] turn on one's possession of particular religious views," 319 US at 634; and the Court's use of the "clear and present danger" test supports reading Barnette as a free expression case. See Lundquist, 278 A2d at 267-73; and Opinions of the Justices to the Governor, 372 Mass at 877-79. Indeed, subsequent Supreme Court cases developing the compelled speech doctrine have relied on Barnette in contexts containing no free exercise issue. See Pacific Gas \& Elec. v California Public Utilities Comm., 475 US 1, 10-11 (1986). See also Employment Div. Dept. of Human Resources of Oregon v Smith, 1990 US LEXIS 2021, *16-17 (characterizing Barnette as a case decided "exclusively" upon free speech grounds). 
pression of speech. ${ }^{11}$ Thus, the Court held, as forms of compelled speech and compelled symbolic expression, coerced recitation of the Pledge and physical salute infringed on constitutionally protected interests. ${ }^{12}$

The Court found no "clear and present danger" to national interests that could justify such an infringement of the students' rights to freedom of expression; compelled speech was not a permissible means of achieving national unity. Attempts to compel unity were perceived as futile and perhaps even destructive of their intended ends. Indeed, the Court noted, underneath the First Amendment lies a constitutional judgment that a nation is stronger when it allows "individual freedom of mind in preference to officially disciplined uniformity." ${ }^{\prime 3}$

Barnette was the first case to recognize that the First Amendment protects the individual's decision not to speak as well as his decision to speak. While later cases relying on Barnette protected individuals from requirements to disclose more or less "factual" information, ${ }^{14}$ Barnette itself addressed the issue of a governmentally-compelled statement of what is variously labeled a "belief," "idea," "creed," "attitude," "sentiment," or "opinion."15 Notably, the Court distinguished the declaration of belief entailed in Pledge recitation from instruction in history and civics, or even instruction intended to "acquaint" students with the content and meaning of the Pledge. ${ }^{16}$ While recognizing that such "study" might, like the Pledge, "tend to inspire patriotism," the Court nevertheless viewed it as within the power of the state; this "slow and easily neglected route" to arouse loyalties could not, however, be shortcut by substituting a "compulsory salute and slogan."17

\section{B. Barnette's Implications for the Teacher Pledge Requirement}

Barnette contains much that is important for determining whether public school teachers may be compelled to recite the Pledge of Allegiance or to salute the flag: it creates a forced speech

\footnotetext{
11 Barnette, 319 US at $633,634$.

12 Id at $632-34$.

13 Id at 636 . (1988).

${ }^{14}$ See, for example, Riley $v$ National Federation of the Blind, 487 US 781, 797-98

${ }^{15}$ Barnette, 319 US at $631,633,634,636,640,642$.

${ }^{16}$ Id at 631 .

17 Id (footnotes omitted). Although the Court did not explicitly acknowledge it, the "study" category presumably would include coerced speech on the part of the student, as where a student is required to answer a history examination question.
} 
doctrine; it recognizes that the Pledge can reasonably be interpreted as a "declaration of belief,"18 and asserts that compelled expression of this type is subject to the highest level of judicial scrutiny; and it contains forceful and often sweeping disparagement of "national unity" as the type of interest that could or should be achieved through compelled affirmation.

Nevertheless, Barnette does not of its own force resolve the teacher Pledge issue; there are differences between the Barnette situation and the teacher Pledge requirement that some courts ruling on the latter issue have, rather surprisingly, failed to consider explicitly.

The intent of the school board resolution in Barnette is different in an important respect from the likely intent of requiring teachers to recite the Pledge. Requiring students to say the Pledge is meant to instill "ideals of Americanism" in the speaker. While modern legislators might be pleased if requiring a teacher to recite the Pledge in class had the incidental effect of enhancing her patriotism, the legislators' principal intent is surely to instill love of country not in the speaker but in the schoolchildren, who witness-and perhaps voluntarily follow-their teacher's example. ${ }^{19}$

In Barnette itself there is language that would seem to require distinguishing between the purely coercive indoctrination at the heart of a student Pledge requirement and the more persuasive inculcative function of requiring teachers to say the Pledge. Addressing the school board's argument that national unity might be lost without a student Pledge requirement, the Court noted that "[n]ational unity as an end which officials may foster by persuasion and example is not in question. The problem is whether under our Constitution compulsion as here employed is a permissible means for its achievement."20 The Court here seems to presuppose the presence of teachers instructed to lead students in civic exercises. Of course, to posit, as the Court did in Barnette, that "indoctrination by example" does not violate students' rights is not to say that it might not independently violate teachers' rights; that issue was not before the Court in the case. ${ }^{21}$ Nonetheless, the Court's

18 Barnette, 319 US at 633.

19 See, for example, Md Education Code Ann \$\$ 7-105(a), 7-105(c)(3) (1986) (expressing the aspiration that "love of freedom and democracy, shown in the devotion of all true and patriotic Americans to their flag and country, be instilled in the hearts and minds of the youth of America").

${ }^{20}$ Barnette, 319 US at 640.

11 The Supreme Court has in fact interpreted Barnette expansively in this respect. See, for example, Wooley v Maynard, 430 US 705, 715 (1977) ("Here, as in Barnette, we are 
distinction does introduce the issue of a state's authority over its paid agents; this poses questions different from those found in Barnette, and for a fuller resolution of the issue we must look to Supreme Court doctrine regarding the free speech rights of public employees.

\section{Public Employee Freedom of Expression Cases}

\section{A. The Pickering Standard}

When the state compels a teacher to recite the Pledge, it acts both as the government and as an employer. It is well established that a government's status as an employer does not absolve it of the First Amendment obligations it bears as the state, and that in certain circumstances a government is barred from applying not only the usual criminal and civil sanctions against its employees, but also employment-related sanctions like dismissal. The Court has also made clear that a government cannot require a prospective employee to relinquish her First Amendment rights as a prerequisite to obtaining government employment. ${ }^{22}$

The leading case in the area is Pickering $v$ Board of Education, ${ }^{23}$ and subsequent decisions have given rise to a two-step analysis of the constitutionality of restrictions on employee speech. Under the first, "public concern" prong of the Pickering test, a court must determine whether the topic of the speech at issue meets a "political" or "social" concern threshold requirement. ${ }^{24}$ For a statement to reach the level of public concern, it must be more than a "mere extension[]" of an employee's "dispute" with her superiors over a job-related issue; it must have the character of

faced with a state measure which forces an individual, as part of his daily life ... to be an instrument for fostering public adherence to an ideological point of view he finds unacceptable."). In fact, much of the language of Barnette suggests very broad rights against compelled expression:

If there is any fixed star in our constitutional constellation, it is that no official, high or petty, can prescribe what shall be orthodox in politics, nationalism, religion, or other matters of opinion or force citizens to confess by word or act their faith therein. Barnette, 319 US at 642 .

${ }^{22}$ See Pickering $v$ Board of Education, 391 US 563 (1968). See also Connick v Myers, 461 US 138, 143-44 (1983), and Rankin v McPherson, 483 US 378 (1987). On requiring teachers to surrender First Amendment rights as an impermissible unconstitutional condition, see Pickering, 391 US at 568.

${ }^{23} 391$ US 563 (1968).

24 See Connick, 461 US 138 (holding that a public employee's circulation of a questionnaire among coworkers concerning, among other things, office transfer policy and whether employees "had confidence in and would rely on the word" of their superiors was not speech on a matter of public concern). 
a statement made by the public employee "as a citizen." 25 Although the Court locates the right and the "interest" in free expression in the employee, ${ }^{28}$ the existence of a public concern criterion and the language of the opinions make it clearer than in some other types of freedom of expression situations that one underlying value is the "public interest in having free and unhindered debate on matters of public importance."27 However, the fact that a statement is "on a matter of public concern" is not the same as the public actually being concerned that the speaker is making it. ${ }^{28}$

If the employee speech at issue passes the public concern threshold, the court then goes on to ask whether the employee's interest "as a citizen" in engaging in the particular expression outweighs the interest of the state, "as an employer, in promoting the efficiency of the public services it performs through its employees." 29 Thus, in Pickering, after finding that the teacher's letter to a local newspaper criticizing school board expenditures "clearly concerns an issue of general public interest,"30 the Court balanced the interests involved and concluded that the letter had not caused harm to the maintenance of discipline by immediate superiors, harmony among coworkers, relationships of personal confidence and loyalty, the teacher's work, or the operation of the schools in general. ${ }^{31}$

\section{B. The Teacher as Public Employee}

Because a public school teacher is a public employee (and especially because a requirement that she recite the Pledge in class is

2s Id at $146-48$ \& $n 8$.

28 Pickering, 391 US at 568.

${ }^{27}$ Id at 573.

28 Speech on a matter of public concern might not generate public interest and controversy for a number of reasons. For example, the public might agree with the speaker, but be apathetic about trying to effect change. Or public disbelief in a statement that would otherwise be of great interest might cause the public to ignore it. See Pickering, 391 US at 570. Similarly, the fact that the speaker is not a prominent person with special expertise in a subject should not ordinarily affect whether his expression is "on a matter of public concern." See Rankin, 483 US at 386 (data entry employee's implicit "criticism" of President's policies found to be on a matter of public concern).

29 Id at 568. The public concern threshold was not clearly set forth in Pickering. See id at 568, 570-74. But in Connick, 461 US 138, the Court made explicit the nature of the "public concern" factor as a threshold test.

so Pickering, 391 US at 571.

${ }^{31}$ Id at 573. 
based on that status), the public employee freedom of expression doctrine is the appropriate framework for consideration of the teacher Pledge issue. Difficulties in applying this test, however, arise not only from ambiguities in the test itself, but also from sharp differences between the Pledge requirement case and the context in which Pickering's test has developed.

\section{The Pledge as speech on a matter of public concern.}

Of the two parts of the test, the public concern criterion is the easier to apply to the Pledge requirement. It is adaptable to compelled speech in two different ways, and under either the public concern requirement is met.

Under the first, more technical modification of the public concern test, a refusal to make a statement qualifies if either making or negating the statement would be expression on a matter of public concern. The Court has specifically included "political" expression within the definition of public concern ${ }^{32}$ and the Pledge of Allegiance is paradigmatic political speech, ${ }^{33}$ the express negation of which likewise would involve political criticism, either of current institutions or of current public values. ${ }^{34}$ Thus, refusing to recite the Pledge falls into the category of speech involving public concern under the first test.

A second method of adapting the public concern test to compelled speech turns on the type and context of the requirement itself. One could argue that the public concern test is met for all forced affirmation of belief. ${ }^{35}$ It is hard to imagine an affirmation of belief that a state employer would have an interest in forcing an

32 Connick, 461 US at 146.

ss Barnette, 319 US at 633 (The Pledge is a "communicat[ion] by word and sign [of a person's] acceptance of the political ideas it thus bespeaks."). See also id at $634 \mathrm{n} \mathrm{14}$, stating that even the use of the word "Republic" in the Pledge could "open up old and bitter controversies in our political history." Note that Pickering and Connick relied on cases holding that compelling public employees to take loyalty oaths violated their right of freedom of expression and association, implicitly acknowledging that such expression involved matters of public concern. Pickering, 391 US at 568; and Connick, 461 US at 144.

se An express negation of the Pledge could not be classified as an "employee complaint[] over internal office affairs," which Connick distinguishes from true political speech. 461 US at 149. A teacher's refusal to say the Pledge might, of course, cause a dispute with her superiors, but the content of the Pledge itself relates to her views as a citizen, not as an employee.

ss This category would not include required disclosure of factual information or required speech such as an employee's answering "yes" when asked if he will obey a request to perform a lawful task within the scope of his duties. See Connick, 461 US at $163 \mathrm{n} 3$ (Brennan dissenting). 
employee to make that would not be on a matter of public concern. If, for example, as happened in the case of Connick $v$ Myers, ${ }^{36}$ a public employee releases to the public a survey questioning office transfer policy, the statement might convey no information other than "the fact that a single employee is upset with the status quo";3 if, on the other hand, the employer tries to force the employee to avow, "I have confidence in and would rely on the word of all my superiors," that suggests some problem or cover-up sufficient to turn the matter into one of public interest. ${ }^{38}$

The claim that forced affirmation of belief will almost always meet the public concern requirement is even stronger when the requirement to speak is placed on a teacher in the classroom; her role is always a public role in some sense, and what she refuses to communicate and what she communicates by refusing to speak are very likely to be of public concern-to her students, to their parents, and to all who will come into contact with these children when they become adult citizens. In sum, when the public concern test is adapted to the forced speech context, it is clear that requiring a teacher to recite the Pledge in the classroom involves "expression" on a matter of public concern, since (1) the Pledge itself involves political speech; (2) it involves an affirmation of personal belief and commitment; and (3) the purpose of the requirement is to influence the beliefs of students as citizens.

2. Compelled Pledge recitation: balancing the teacher's right and the school's interest.

Once it is determined that the teacher's refusal to recite the Pledge is expression on a matter of public concern, the next step under Pickering is to balance the teacher's interest in refusing to speak against any interest the state has in dictating the teacher's speech. In Pickering, the Court described a number of specific factors to be considered in ascertaining the state's special interest as an employer. Applying the balancing test to the Pledge requirement is different from applying it to expression in other public employee cases, however, because one of the factors weighed is

\footnotetext{
36 Id at 141.

${ }^{37}$ Id at 148.

ss See id at 141.
} 
whether the teacher's "performance" is impaired.99 Although there is no reason to believe that the teacher's performance of duties other than saying the Pledge is impaired by her refusal, ${ }^{40}$ the failure to say the Pledge (if saying the Pledge is in fact an appropriate part of her duties) undeniably impairs her performance. The question ultimately must be: is reciting the Pledge (when the teacher does not wish to do so) a proper part of her mandatory duties? If the state's description of employees' duties were not subject to judicial scrutiny, the state could always circumvent its employees' constitutional rights simply by claiming that their duties include not behaving in ways that amount to exercise of those rights.

In Pickering, analysis of impairment of duties involved consideration of other duties not at issue and assumed to be legitimate. ${ }^{41}$ If the Court had been faced in Pickering with an explicit assertion by the state that Pickering's duties included not making any statements about school functions to the press, the Court presumably would have stepped back to conduct its balancing test at this level. The state's assertion that activities are part of an employee's duties is always explicit when it attempts to compel speech or association. To determine whether the teacher Pledge recitation requirement is constitutional, then, we must balance the state's incremental interest in compelling that particular form of speech against the employee's interest in not being compelled. The next section addresses three areas of law-compelled speech, loyalty

39 Id at 572-73. Most of the other factors that the Pickering line of cases require a court to consider involve whether the expression created disharmony with supervisors or coworkers. See, for example, Pickering, 391 US at 569-70. In discussing this consideration, the Pickering Court pointed out that the criticism was not "directed towards" those persons. A teacher's refusal to recite the Pledge, if it is interpreted as an implicit criticism of anything (rather than mere failure to praise) is certainly not a criticism "directed towards" her superiors or coworkers. General First Amendment principles require that persons tolerate disagreements of opinion with others, especially when "criticism" is not aimed directly at them. See Gooding $v$ Wilson, 405 US 518 (1972); and Cohen v California, 403 US 15 (1971). Indeed, in Rankin the Court apparently gave no weight to the fact that the employee's statement (wishing would-be assassins better luck next time in shooting President Reagan) had upset a co-worker. See 483 US at 400 (Scalia dissenting). In sum, Pickering and its progeny do not foreclose an argument that a court should give no weight to upset on the part of other teachers at one teacher's "unpatriotic" refusal to recite the Pledge.

${ }^{\circ}$ This assumes there is no evidence of improper motivation to upset parents or students. Such motivation should not be presumed, since a teacher might refuse to say the Pledge for many reasons. See Barnette, 319 US at $634 \mathrm{n}$ 14; id at 645 (Murphy concurring); Lundquist, 278 A2d at 266, 274-75; Russo, 469 F2d at 626, 634; and Hanover, 325 F Supp at 171.

41 "[The employee's public statements have not] impeded the teacher's proper performance of his daily duties in the classroom." Pickering, 391 US at 572-73. 
oaths, and freedom of expression in the public schools-that give content to each side of the balancing equation.

\section{Supreme Court Doctrine Bearing on the Interests of Teacher and School}

\section{A. The Pledge as Compelled Affirmation of Political Belief}

In Wooley $v$ Maynard, ${ }^{42}$ state statutes required automobiles to bear license plates containing the state motto, "Live Free or Die," and prohibited car owners from obscuring these words. In holding that the statutes violated the First Amendment, the Court stated that forcing someone to foster "religious, political, and ideological" causes invaded "the sphere of the intellect and spirit" protected in Barnette. The Court conceded that compelling the affirmative act of flag salute was a "more serious infringement upon personal liberties" than the passive act involved here, but it viewed the difference as one of degree. ${ }^{43}$ The asserted state purposes, the Court concluded, could not justify even this degree of infringement. To override the individual's interest in not being a "courier" for a state message, the justifying purpose must be substantial and the means used must be the least drastic possible. ${ }^{44}$ The Court rejected one of the avowed purposes of the license plate logo-to promote appreciation of "history, individualism, and state pride"-because it was not "ideologically neutral."45 Although the state might legitimately pursue such an interest in a number of ways, the Court said, dissemination of an ideology, "no matter how acceptable to some," could not outweigh an individual's First Amendment right to avoid becoming its courier. ${ }^{46}$

In PruneYard Shopping Center $v$ Robins, ${ }^{47}$ by comparison, the Court held that shopping mall owners could be forced to open their property to expression by members of the public, and purported to distinguish Wooley in several ways. First, the Court explained, because the shopping center was open to the public, the views expressed there by some members of the public were not likely to be identified as the owners'. Moreover, the owners of the

42430 US 705 (1977).

${ }^{48}$ Id at 715. In dissent, then-Justice Rehnquist argued that the First Amendment applied only where, as in Barnette, the state requires a person apparently or actually to "assert [a message] as true." Id at 721 (Rehnquist dissenting).

"Id at 716.

${ }^{45} \mathrm{Id}$ at 716-17.

18 Id at 717.

17 447 US 74, 87 (1980). 
shopping center could expressly disavow connection with the message by, for example, posting signs. ${ }^{48}$ Finally, in this case, unlike Wooley, no special message was dictated by the state, so there was no danger of government discrimination for or against a particular message.

Both Wooley and PruneYard suggest that compelling a teacher to recite the Pledge significantly infringes her freedom of expression. Although neither case involved a public employee, ${ }^{40}$ both recognized the strong interest an individual has in not being forced to affirm political or "ideological" beliefs. Moreover, each case recognized that a requirement to recite an unambiguous specific verbal assertion of a message "as true" is a particularly serious infringement..$^{\text {so }}$

In addition, a teacher Pledge requirement is closer to Wooley than to PruneYard. First, as in Wooley, the government specifies the ideological message. ${ }^{\text {s1 }}$ Second, because of its form as a verbal affirmation of belief, a teacher's recitation of the Pledge is especially likely to be taken, by students or others who witness it or hear of it, to represent the teacher's actual beliefs; indeed, that is very probably what the school hopes in compelling the recitation..$^{52}$ Finally, under PruneYard, even if a state compelled the teacher to recite the Pledge but then allowed her to expressly or implicitly

\footnotetext{
${ }^{48}$ In his PruneYard concurrence, Justice Powell argued that the Court had inappropriately emphasized the mall owners' ability to speak out affirmatively or to disavow agreement with the views expressed by members of the public. The Court left the property owner with the dilemma of either permitting customers to receive the mistaken impression that the owner agreed, or of disavowing the message when he would prefer to remain silent. Further, if the property owner was forced to use his property for speakers with views he found "morally repugnant," he might feel compelled to speak out against these views, even where they would not be mistaken for his own. 447 US at 99-100. See also Pacific Gas \& Elec., 475 US at 15-16.

19 But see Abood v Detroit Board of Education, 431 US 209 (1977) (public employer cannot, as a condition of employment embodied in a collective bargaining agreement, force public employees to pay fees to a union to be used to express political views and support ideological causes).

so Wooley, 430 US at 715; and PruneYard, 447 US at 88.

81 The fact that the Pledge recitation requirement combines state selection of the message with an implied assertion that the teacher personally adheres to that message may justify greater concern regarding the state's skewing of the "marketplace of ideas." See generally Alexander Meiklejohn, Free Speech and Its Relation to Self-Government 26 (Harper, 1948), cited in Board of Education v Pico, 457 US 853, 867 n 20 (1982) (persons denied acquaintance with doubt or disbelief or criticism relevant to an issue are not well-armed to participate in self-government).

52 Even if the students do not assume that the teacher herself "believes" in the Pledge, or even if she is allowed to "cure" this misconception by disaffirming it, her interest in keeping her political beliefs private is necessarily infringed. See note 48 .
} 
disavow the views, ${ }^{63}$ the purpose of the Pledge requirement would be frustrated: to provide not just cold instruction about the Pledge, but a role model.

\section{B. The Loyalty Oath Cases}

The compelled speech cases above involved private citizens. Another line of "compelled speech" cases concerns individuals required, as a condition of public employment, to take "loyalty" oaths that could be construed as promises of future conduct or allegiance, or as affirmation of current belief. Like the teacher Pledge requirement, these cases involve explicit verbal affirmations of commitment to the United States and its form of government, recited by a public employee as a condition of her employment. Notably, the Court in Barnette characterized the Pledge as a "credo of nationalism" and an "affirmation of belief." A concurrence stated that the Pledge is "a form of test oath, and the test oath has always been abhorrent in the United States."

In Baggett $v$ Bullitt, the Court struck down on vagueness grounds a statute requiring teachers to take an oath that they would "by precept and example promote respect for the flag and the institutions of the United States and the State of Washington [and promote] reverence for law and order and undivided allegiance to the government of the United States." cepted the complainants' claim that they could not "understand the required promise, ... . define the range of activities in which they might engage in the future, and [did] not want to forswear doing all that is literally or arguably within the purview of [its] vague terms."

In Cole $v$ Richardson, ${ }^{58}$ the Court summarized several tests that an oath requirement must meet. The state could not "condi-

ss The "compromise" of allowing the teacher to disaffirm only outside the classroom restricts the teacher's ability to correct misimpressions among those most likely to be misled without ensuring that the students will not find out the teacher's view anyway. See James $v$ Board of Education of Central Dist. No. 1, 461 F2d 566, 572 n 13 (2d Cir 1972).

s. Barnette, 319 US at 633-34.

ss Id at 644 (Black and Douglas concurring).

s6 377 US 360, 361-62 (1964). Among a number of actions that the Court postulated could violate the oath was a teacher's refusal to salute the flag (or her advocacy of such refusal) because of religious beliefs. Id at 371. The Court cited Barnette, suggesting that it might have believed that the state could not constitutionally require the teacher to salute the flag.

s7 Id at 378. Among the vague phrases causing the Court concern were "respect," "institutions," and "promote ... allegiance."

s8 405 US 676 (1972). 
tion employment on taking oaths that impinge on rights guaranteed by the First and Fourteenth Amendments, respectively, as for example, those relating to political beliefs." 59 The oath could not contain a promise that one had not engaged or would not engage in protected speech activities or protected associations. Finally, the oath could not be so vague that "men of common intelligence must necessarily guess at its meaning and differ as to its application."

Though the loyalty oath cases concerned statutes struck down on overbreadth and vagueness grounds, consideration of the decisions is relevant to balancing the interests in the teacher Pledge issue. The Court has frequently acknowledged that many of the harms to individual and state interests stemming from requiring vague or overbroad oaths are theoretically independent of the possibility of perjury prosecution. In Baggett, for example, the Court noted that even if there was no possibility of enforcement of a vague oath through perjury prosecution, the oath requirement was unconstitutional: to hold otherwise would ignore "the effect of the oath on those who will not solemnly swear unless they can do so honestly and without ... reservation."61 Moreover, the public interest, as well as the individual oath-taker's interest, was involved: excluding from public employment those persons scrupulous enough to refuse to swear would encourage the casual taking of oaths; ${ }^{62}$ and individuals of integrity might avoid public service rather than compromise their commitment to intellectual freedom. ${ }^{63}$

One can argue that some of the state's interests in requiring daily classroom recitation of an oath by teachers differ from the state's interests in requiring a single nonpublic recitation of an oath by employees generally. With true loyalty oaths, only the speaker's "qualifications" and fitness for his job are tested (or perhaps created by a promise of future conduct). The Pledge recitation requirement is placed on the teacher primarily to inculcate values and beliefs in students. Whether that difference in interests can justify compelled recitation in the former situation cannot be decided solely by analysis of the loyalty oath cases; the nature and extent of the state's additional interests as an educator must be considered as well. What these cases do demonstrate, however, is

\footnotetext{
68 Id at 680 .

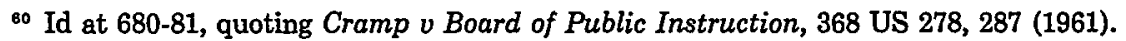

B1 Baggett, 377 US at 374.

B2 Id at 373-74.

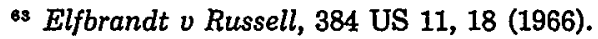


the seriousness with which we should view infringement on the conscience of a public employee forced to affirm beliefs or make promises, as well as the harm to the public-in terms of foregone speech or activities, loss of some individuals who might have been its most sincere and valuable employees, and trivialization of the oath itself-occasioned by compelling any oath of loyalty.

\section{The Schoolhouse Cases}

1. Ideological training and the importance of free inquiry in the schools.

A public school teacher is a public employee, but her responsibilities as an instructor and role model mean that placing speech or belief restrictions on her might involve interests somewhat different from those invoked to justify similar constraints on other employees. In terms of the public employee's interest, the loyalty oath cases are structurally the most analogous to the teacher Pledge requirement. The Pledge requirement, however, is unique in that the state imposes it primarily to educate students-or more specifically, to instill patriotic values in them-rather than to determine the teacher's fitness or to extract a promise from her that she will perform her job in a certain way.

While the Court does not treat all situations involving both First Amendment interests and public education as falling within a single doctrinal category, a line of cases that adapts other doctrines to the "schoolhouse" setting and mission has emerged. The constitutional provisions invoked to protect individual rights or interests in these cases vary greatly. "Schoolhouse expression" and "academic freedom" arguments have been considered where claims were based on substantive due process, ${ }^{64}$ freedom of religion, ${ }^{65}$ and freedom of expression or association. Claims in the last category include those challenging requirements that teachers take loyalty oaths or disclose information implicating associational rights; ${ }^{66}$ various restrictions on expression of students in schools and uni-

4 Meyer v Nebraska, 262 US 390 (1923).

as Epperson v Arkansas, 393 US 97 (1968) (state statute making it unlawful for teacher in a state-supported school to "teach" theory of evolution violated Establishment Clause).

es Wieman v Updegraff, 344 US 183, 195 (1952) (Frankfurter concurring); Keyishian v Board of Regents, 385 US 589, 601 (1967); Whitehill v Elkins, 389 US 54, 59-60 (1967); Shelton v Tucker, 364 US 479, 487 (1960); and Sweezy v New Hampshire, 354 US 234, 250 (1957). 
versities; ${ }^{67}$ decisions by school boards to remove books from school libraries; ${ }^{68}$ and the expressional rights of citizens while on grounds surrounding the school. ${ }^{68}$

As in the public employee speech cases, ${ }^{70}$ the usual First Amendment tests are modified in light of the government interests and purposes-here, controlling school activities in order to educate students. ${ }^{71}$ But modifying speech rights for the schoolhouse context does not mean simply decreasing those rights. ${ }^{22}$ Rather, the Court's opinions recognize a tension between the greater need for state control of expression on publicly-owned property set aside for special purposes, especially for ideological training and other educational purposes, and the fact that, to fulfill those purposes, schools must to some extent be places of free exchange. ${ }^{73}$ Among

${ }^{67}$ Tinker $v$ Des Moines Independent Community School Dist., 393 US 503 (1969); Healy v James, 408 US 169 (1972); Papish v Board of Curators of University of Missouri, 410 US 667 (1973); Bethel School Dist. v Fraser, 478 US 675 (1986); and Hazelwood School Dist. v Kuhlmeier, 484 US 260 (1988) (high school principal's content-based decision to restrict publication of certain articles by students in school newspaper did not violate First Amendment).

es Pico, 457 US at 870 (school board's discretion in removing books from secondary school library may not be exercised "in a narrowly partisan or political manner").

${ }^{69}$ The Court has treated the grounds surrounding a school as a limited public forum, asking whether a noise or diversion is "basically incompatible" with the normal activity of the school at a particular time. Grayned v Rockford, 408 US 104, 116-20 (1972).

${ }^{70}$ Then-Justice Rehnquist, concurring in the result in Healy, drew this specific parallel, comparing public college discipline cases with cases such as Pickering: "The government as employer or school administrator may impose upon employees and students reasonable regulations that would be impermissible if imposed by the government upon all citizens." 408 US at 203 (Rehnquist concurring). See also Pico, 457 US at 908 (Rehnquist dissenting).

${ }^{71}$ In Healy, for example, the Court described the current test for criminal advocacy of illegal conduct (from Brandenburg $v$ Ohio, 395 US 444, 447 (1969)), as drawing a distinction between "mere advocacy and advocacy 'directed to inciting or producing imminent lawless action and ... likely to incite or produce such action," " but pointed out that the special characteristics of the school environment gave the government power to prohibit even some non-criminal "lawless action." 408 US at 188-89.

72 See Healy, 408 US at 180-81. Compare the Court's treatment of restrictions on expression on other state-owned property and in other state-controlled contexts. See Adderley v Florida, 385 US 39 (1966) (jail); Greer v Spock, 424 US 828 (1976) (military base). "In our system, state-operated schools may not be enclaves of totalitarianism." Tinker, 393 US at 511.

73 See, for example, Pico, 457 US at 879 (Blackmun concurring in part and concurring in the judgment). Barnette created the analytical tension between unconstitutional prescriptions of orthodoxy and proper fostering of "[n]ational unity." 319 US at 642, 640. Even current cases viewed as expanding First Amendment rights continue to acknowledge the propriety of ideological training in schools. See, for example, Pico, 457 US at 864. Cases such as Pico, however, might be viewed as resolving the tension between the ideological training purpose of schools and First Amendment constraints on "prescriptions of orthodoxy" by limiting the degree to which student exposure to the "orthodox" ideas can intentionally be made exclusive, rather than by rejecting particular means of inculcation. 
the reasons for according special protection to expression in the school, which is "peculiarly the "marketplace of ideas," "74 are that free inquiry is conducive to learning; ${ }^{78}$ that new discoveries may thereby be made; ${ }^{76}$ that students should be taught open-mindedness; ${ }^{77}$ and that students should be taught tolerance. ${ }^{78}$ Even where the constitutional rights claim is rejected, the Court has cited the importance of openness in schools, rather than the need for strict control over the minds of the young. ${ }^{79}$

In considering the effect of the "schoolhouse" cases on the Pickering balancing, then, it is important to remember the complexity of the interests involved. Although Pickering and later public employee cases locate the speech right in the individual employee, their language and use of a "public concern" threshold suggest that the Court is not simply balancing an individual employee's personal interest in free expression against concededly strong interests of the state (and the public it represents) in favor of restricting that speech. Rather, the Court is also concerned that restricting employee speech will in fact disserve "public" interests-for example, the interest in improving the government's performance of its functions in response to criticism leveled at it by those most knowledgeable. ${ }^{80}$ Similarly, in weighing free speech interests against state interests in the public school context, the Court recognizes that some degree of freedom of expression is necessary to fulfill educational purposes. ${ }^{81}$

Like the forced speech cases, many of the schoolhouse cases do not involve free speech rights of public employees; extension of their reasoning to the teacher Pledge requirement must be undertaken carefully, since the teacher is, and is paid to be, a role model for her students. ${ }^{82}$ This distinction, however, should not be given

74 Keyishian, 385 US at 603.

78 Sweezy, 354 US at 250; and Pico, 457 US at 868.

3e Sweezy, 354 US at 250.

${ }^{77}$ Adler v Board of Education, 342 US 485, 511 (1952) (Douglas dissenting); and Wieman, 344 US at 196 (Frankfurter concurring).

78 Bethel, 478 US at 681.

79 See, for example, Adler, 342 US at 489-90 (upholding a law preventing members of groups advocating overthrow of the government by unlawful means from working in public schools).

so See text at note 27.

81 Thus Pico, a schoolhouse free expression case, acknowledged that the First Amendment is concerned not only with fostering individual self-expression but also with " affording the public access to discussion, debate, and the dissemination of information and ideas.' " 457 US at 866, quoting First National Bank of Boston v Bellotti, 435 US 765, 783 (1978).

83 Adler, 342 US at 493; and Ambach v Norwick, 441 US 68, 78-79 (1979). 
too much weight for several reasons. The language of the Supreme Court cases dealing with students' free speech rights in the schools is deliberately broad, encompassing teachers as well as students. ${ }^{83}$ The reasoning of the cases is similarly broad; the opinions, for example, do not so much emphasize the degree of infringement on the interests of individual students (who, unlike the teacher, are usually required to attend school), as stress the benefits of free exchange in the schools. ${ }^{84}$ Finally, the tension between the school's role in inculcating values and the need for free exchange is mirrored in the tension between conceptions of the teacher's role. The teacher is concededly a shepherd guiding her students in the acquisition of values, but what values? In Wieman $v$ Updegraff, ${ }^{85}$ a case striking down a loyalty oath requirement imposed on a college teacher, Justice Frankfurter, writing in concurrence, pointed out that "[i]t is the special task of teachers to foster those habits of open-mindedness and critical inquiry which alone make for responsible citizens .... . Teachers must fulfill their function by precept and practice, by the very atmosphere which they generate; they must be exemplars of open-mindedness and free inquiry."

2. Tinker's disruption test and the free expression rights of teachers.

In Tinker $v$ Des Moines Independent Community School Dist. ${ }^{87}$ the Court stated,

First Amendment rights, applied in light of the special characteristics of the school environment, are available to teachers and students. It can hardly be argued that either students or teachers shed their constitutional rights to freedom of speech or expression at the schoolhouse gate.

In Tinker, high school and junior high school students were suspended for wearing armbands to school to protest the Vietnam War. Emphasizing the need for control over conduct in the schools, ${ }^{88}$ the Court nevertheless held that the First Amendment's protections apply unless the conduct at issue "materially disrupts

8s See, for example, Tinker, 393 US at 506.

4 Tinker, 393 US at 512. See also Pico, 457 US at 870 , relying on Mt. Healthy City Board of Education v Doyle, 429 US 274 (1977), a teacher free speech case, to limit a school board's discretion in removing books from the school library.

Bs 344 US 183 (1952).

8s Id at 196 (Frankfurter concurring).

87 393 US 503, 506 (1969).

Id at 507 . 
classwork or involves substantial disorder or invasion of the rights of others." 89

Several lower courts have attempted to apply the Tinker "disruption" test to the teacher Pledge issue..$^{90}$ Tinker's use of the term is ambiguous, however, and the ambiguities are exacerbated when Tinker is applied to forced speech by teachers. This subsection will describe different types of classroom expression that might be classified as "disruptive," and will argue that "disruption" should not be construed to include a teacher's refusal to recite the Pledge.

a) Schoolhouse expression as "disruptive" if it physically interferes with the persons of others or their ability to communicate. Some of the language in Tinker suggests that determining "disruptiveness" is akin to distinguishing between action and speech, or between the manner of speech and its content. ${ }^{91}$ The student who fights with other students in an attempt to express his views, or who "stands on a soapbox during calculus class to deliver an eloquent political diatribe"92 is clearly engaging in "disruptive" expression. While a teacher could conceivably act violently or boisterously, a refusal to speak would never constitute "disruption" under this limited view.

b) Teacher's affirmative expression as "disruptive" if engaging in that expression prevents her from teaching a statemandated curriculum. If a teacher talks about a subject that is not in the curriculum or injects her opinions into what is supposed to be a lesson teaching the facts, her behavior may constitute "disruption" because it takes scarce time away from subjects the teacher is supposed to teach. ${ }^{83}$

Encompassing such behavior within the "disruption" standard seems justified. The school has the right to define the basic curriculum; certainly none of the Supreme Court cases suggests that a

89 Id at 513.

so See, for example, Hanover, 325 F Supp at 172-73; and Russo, 469 F2d at 632-33.

21 Tinker, 393 US at 505-06, 508 (noting that the students had engaged in only "a silent, passive expression of opinion, unaccompanied by any disorder or disturbance"). See also Russo, 469 F2d at 633; and Lundquist, $278 \mathrm{A2d}$ at 274.

92 Hazelwood, 484 US at 279 (Brennan dissenting) (classifying this type of disruption as "direct" interference with school functions).

9s "[A] teacher is not paid to go into school and teach subjects the State does not hire him to teach as part of its selected curriculum." Tinker, 393 US at 522 (Black dissenting). If a teacher allocates substantial time to covering materials not specified in the state's curriculum, disruption of that curriculum might be presumed, even where the state does not offer evidence that any particular mandated lessons have been sacrificed. 
teacher must be given complete free reign to choose what to teach. Whether the school can assert an absolute right to prevent any affirmative expressive activities by the teacher in the classroom is a difficult question. A teacher's refusal to recite the Pledge, however, is a failure to speak, and as such, cannot be condemned as an insistence on "teaching" subjects the state has not hired her to teach. Under this second definition of "disruption," then, a teacher may or may not be "disrupting" the school's work when she states (one or a dozen times) that she opposes the Vietnam War, but she is not "disrupting" the school's work by refusing to make affirmative statements. ${ }^{94}$

c) Schoolhouse expression as "disruptive" if it leads to upset, anger, or protest on part of parents or other members of the community. The previous two interpretations focused on the speaker's actions and speech, not on the resulting emotions, speech, or actions of others. One of the lower courts considering the Pledge issue found the parents' dismay relevant in deciding whether the teacher could be fired. ${ }^{95}$ But the emotional reaction of parents-or members of the community generally-should not be given independent weight in applying the Tinker disruption standard. Upsetting others will not usually justify suppression of speech under general First Amendment principles. ${ }^{96}$ Tinker itself stressed this principle: "In order for the State ... to justify prohibition of a particular expression of opinion, it must be able to show that its action was caused by something more than mere desire to avoid the discomfort and unpleasantness that always accompany an unpopular viewpoint."97 Community reaction should be even less relevant in the case of a teacher Pledge requirement, since upsetting others has never been used to justify compelling speech. Only the disruption of the actual education of the students should be taken into account in delineating schoolhouse expressional rights. ${ }^{98}$

94 The premise of this second interpretation of "disruption" is that when the teacher speaks on one subject, she fails to teach another subject which it is her duty to teach. Of course, if reciting the Pledge can correctly be classified as part of the curriculum that it is the teacher's duty to "teach," she "disrupts" the school's proposed curriculum simply by refusing to recite the Pledge. Failure to perform mandated duties as disruption is analyzed in subsection e below.

${ }^{85}$ Palmer $v$ Board of Education of City of Chicago, 466 F Supp 600, 602 (N D Ill 1979), aff'd, 603 F2d 1271 (7th Cir 1979).

${ }^{88}$ See Terminiello v Chicago, 337 US 1, 5 (1949).

${ }^{87} 393$ US at 509. See also id at 508.

${ }^{28}$ See id at 506. 
d) Schoolhouse expression as "disruptive" if its content is particularly distracting, confusing, or upsetting to students, substantially decreasing their ability to concentrate on their lessons. The foregoing arguments for disregarding other persons' responses to teacher Pledge resistance apply with less force when those other persons are students. The school could, of course, try to punish students for reacting to expression in a disruptive manner, or for failing to concentrate on their lessons. But, ultimately, one cannot expect the same degree of emotional control in children that the courts have demanded of adults in "fighting words" and "offensive speech" cases. ${ }^{9 \theta}$ Since students are a captive audience, and since the purpose of the school is to educate, restrictions on teacher or student speech that is likely to seriously upset students, substantially interfere with their ability to concentrate, or cause them to make disturbances, may be justified.

Some courts considering the Pledge issue have weighed the emotional effect on students. ${ }^{100}$ Tinker's language and outcome require that the expected disruption be substantial, and that proof of likelihood of that disruption be specific; ${ }^{101}$ Tinker itself protected expression on a highly controversial and emotion-provoking topic. ${ }^{102}$ It seems unlikely that a refusal to speak could ever cause a great enough degree of student disruption to justify compelling speech. ${ }^{103}$

20 See FCC v Pacifica, 438 US 726, 749-50 (1978); id at 756-58 (Powell concurring in part and concurring in the judgment); and Bethel, 481 US at 682.

${ }^{100}$ See, for example, Palmer, 466 F Supp at 603-04.

101 "In order for the State in the person of school officials to justify prohibition of a particular expression of opinion, it must be able to show that its action was caused by something more than a mere desire to avoid the discomfort and unpleasantness that always accompany an unpopular viewpoint. Certainly where there is no finding and no showing that engaging in the forbidden conduct would 'materially and substantially interfere with the requirements of appropriate discipline in the operation of the school, the prohibition cannot be sustained." 393 US at 509, quoting Burnside v Byars, 363 F2d 744, 749 (1966).

${ }^{102}$ The students' protest of the Vietnam War came at a time when friends of a former student who had been killed in Vietnam still attended the school. 393 US at $509 \mathrm{n}$ 3. But the resulting hostile remarks (without threats of violence) did not constitute the necessary degree of disruption. Id at 508.

${ }^{103}$ The Court in Barnette did not even consider that other students might become upset, distracted, or confused when some students in the room did not participate. See also note 39, arguing that upset among other teachers should be irrelevant in determining whether a teacher can be compelled to recite the Pledge. Obviously, if a school official disputes a teacher's refusal to say the Pledge, and does so in front of students, it might upset them, but responsibility for such disruption should be traced to the school, not to the teacher. 
e) Teacher's affirmative expression as "disrupting" lesson plans because its content is contrary to lessons to be taught. Expression might be "disruptive" if it contradicts a view meant to be conveyed by the school, thereby dissuading students from adopting the school's view. There is an ambiguity in Tinker as to whether the disruption standard is meant to encompass the direct effects of the content of expressive activities on inculcation -and as to what types of effects are appropriate justifications for restrictions on schoolhouse expression. ${ }^{104}$ In particular, it is unclear if Tinker was meant to address school officials' attempts to suppress speech that "frustrates the school's legitimate pedagogical purposes merely by expressing a message that conflicts with the school's, without directly interfering with the school's expression of its message." Justice Brennan has stated that, under Tinker, "mere incompatibility" with the school's message cannot justify suppression of student speech. ${ }^{106}$ Nothing in that case even remotely suggests that the school could have prohibited Tinker's armband merely by adopting an official policy in favor of the Vietnam War and then asserting that Tinker was "muddling" students' views on the issue. ${ }^{107}$

Even if Justice Brennan's view of Tinker is correct, however, it is unclear whether affirmative expression by teachers that occurs on school premises and contradicts the school's message must ever be tolerated. ${ }^{108} \mathrm{~A}$ teacher is more likely to be a model for students; indeed, that is one of her functions. The Supreme Court opinions

${ }_{104}$ Contrast Justice White's majority opinion in Hazelwood, 484 US at 271, with Justice Brennan's dissent, id at 279-84. The majority created a new test for school-sponsored newspapers because it believed that the restrictions on "disruptive" expression allowed by Tinker would not include rules that insured that journalism students "learn whatever lessons the activity is designed to teach." Id at 271. According to Brennan, however, that consideration is the "essence" of the Tinker test. Id at 283.

${ }^{105}$ Id at 279 (Brennan dissenting).

${ }^{108}$ Id. See Tinker, 393 US at 511 ("[Students] may not be confined to the expression of those sentiments that are officially approved."); and id at 513.

${ }^{107}$ See Hazelwood, 484 US at 279 (Brennan dissenting). The majority in Hazelwood did not claim otherwise; instead, it adopted a different standard for a newspaper "sponsored" by the school.

108 But see James, 461 F2d at 571-76, which applied Tinker to uphold a teacher's right to wear an armband in class in protest of the Vietnam War. The court also invoked Pickering, rejecting a distinction between teacher expression in school and out of school as "arbitrary." Id at 572 \& $n 13$. 
have much to say that is relevant to this issue, ${ }^{109}$ but none gives a definitive answer. Whatever the answer to that question, forced speech requirements and suppression of affirmative expression involve different considerations. In one sense, the teacher's refusal to speak may be more "disruptive" than her insistence on interjecting her own views; certainly it would seem more disruptive of the educational mission if a librarian refused to order books of which she disapproved, than if she refused to remove a few books of which the school board disapproved. Similarly, if the "disruption" test can be applied to teachers at all, surely a math teacher's failure to teach fractions is disruption, even if she is quiet in her refusal and does not upset the parents or students. "Disruption," then, includes a teacher's refusal to speak where the state may legitimately require her to speak. ${ }^{110}$

But there is a strong argument that the state may not, merely by defining recitation as one of the teacher's duties, force her to affirm a belief or commitment as her own. ${ }^{111}$ First, the background rule established by the schoolhouse cases is that the educational function of the school, in addition to the interests of the individ-

108 Because a teacher is paid by the school to teach, affirmative expression by her in the classroom is arguably more "sponsored" by the school than is the classroom speech of students. On the other, hand, Pico suggests that there are limits on the school's right to "obstruct" the communication of certain messages in the school even when the school is in some sense "sponsoring" that communication; the school may not intentionally prevent access to ideas solely because it disagrees with them, even when the ideas expressed (such as "antiAmerican" ideas) contradict the ideological message that the school is trying to impart. 457 US at 871-73. The objections of the Pico dissents, too, suggest that there might be a stronger justification for protecting teacher expression than for protecting student access to library books: then-Justice Rehnquist argued that the student's right to receive ideas could not be derived from any right to send those ideas because authors have no right that their books be placed in school libraries, id at 912; see also id at 887 (Burger dissenting). Here, the sender is the teacher, who may be argued to hold the correlative right.

${ }^{110}$ This is the most important sense in which a refusal by the teacher might be said to "disrupt" the school's function, but lower courts generally ignore this interpretation, searching instead for evidence of accompanying or consequential disruption. Some of these courts cite Barnette's "grave and immediate" danger test. See Hanover, 325 F Supp at 172; and Opinions of the Justices to the Governor, 372 Mass at 879. But this test is not particularly helpful in determining what duties the state may require of its public employees. Palmer, 466 F Supp at 604, errs in the opposite direction, justifying dismissal of the teacher based on the conclusory statement that she had failed to follow the "curriculum." See also Palmer, 603 F2d at 1272.

121 Because it involves compelled political expression, a requirement to recite the Pledge might be especially problematic. Although the schoolhouse cases consistently acknowledge the propriety of civic education (for example, Pico, 457 US at 864), they also express a particularly strong concern with protecting belief, inquiry, and expression on political matters. See, for example, Sweezy, 354 US at 250; Barnette, 319 US at 637; and Bethel, 478 US at 685-86 (distinguishing Tinker as imposing penalties based on political viewpoint). 
ual, are furthered by freedom of belief and expression. While the loyalty oath and academic freedom cases protect the rights of college teachers, it is the same general principles espoused in those cases that have caused the Court to recognize fairly broad expression rights for students in lower grades. ${ }^{112}$

Second, it must not be forgotten that a teacher is hired to perform a multitude of tasks. If the school hired a professional Pledge-sayer, whose only duty was to move from room to room reciting the Pledge, the state would have the strongest possible interest in having that person recite the Pledge. But a teacher's task is to "foster . . . habits of open-mindedness and critical inquiry."113

Third, many of the concerns that have occupied members of the Court in schoolhouse expression cases are less pressing where compelled speech, particularly compelled affirmation of belief, is involved. Whereas community members might reasonably perceive school-sponsored expressive activities to bear the imprimatur of the school, ${ }^{114}$ one could hardly argue that a person's failure to speak has the school's imprimatur. ${ }^{115}$ Similarly, the rejection of the right of a teacher to "indoctrinate" students into her beliefs ${ }^{116}$ is much less relevant where the teacher asserts a right not to speak, or at least where she asserts a right not to affirm beliefs. ${ }^{117}$ It is true that a teacher's refusal to recite the Pledge prevents ideas from being put forward in a certain manner. But the state's insistence on that manner of expression, the teacher's oath, in preference to the study of the words of the Pledge or the ideas embodied in the Pledge, is insistence not just on communication of those

112 See Tinker, 393 US at 506-07 (relying on numerous academic freedom cases involving teachers' expression rights).

11 Wieman, 344 US at 196 (Frankfurter concurring).

114 Hazelwood, 484 US at 271. See also Pico, 457 US at 889 (Burger dissenting).

11 Hazelwood asserted that the school can refuse to sponsor expression that might associate the school with positions other than "neutrality" on matters of political controversy. 484 US at 272. It seems that no expressiye position can be more neutral than silence.

116 Adler, 342 US at $489-90$.

117 The fact that students became more curious or skeptical about the Pledge should not be relevant in deciding whether a teacher's refusal is protected. Hanover, $325 \mathrm{~F}$ Supp at 173. First Amendment doctrine does not generally allow suppression of ideas merely because the speaker is successful in convincing others. 
ideas, but on communication of a lie: ${ }^{118}$ that the teacher believes those ideas, or is committed to those values. ${ }^{119}$

There is no general Supreme Court doctrine for speech rights of teachers in lower public education: the "academic freedom" cases concern the free speech rights of university professors; the "disruption in lower education cases" concern the rights of students. Yet the same reasons that moved the Court, drawing on "academic freedom" cases, to recognize younger students' expressional rights suggest that teachers should have rights as well. Indeed, if Tinker's considered dictum that teachers do not leave First Amendment rights at the schoolhouse gate is to have any force at all, a requirement that a teacher personally affirm a political conviction as her own presents an extremely strong context for recognizing such rights.

\section{ConcLusion}

The issue of the constitutionality of forcing a public school teacher to recite the Pledge of Allegiance implicates several First Amendment doctrines, doctrines that sometimes overlap and sometimes seem to conflict. This Comment has taken as its structural framework the balancing test applied to affirmative expression by a public employee, invoking Supreme Court precedent on forced speech, loyalty oaths, and expression in the public schools to give content to the two "sides" of the balancing equation. However, as is often the case whenever the public employee test is applied, perhaps whenever free speech rights are delineated, closer scrutiny of the interests reveals that it is not only the public em-

\footnotetext{
${ }^{118}$ A teacher need not assert her disagreement with the Pledge, but only her unwillingness to participate, in order to be excused. While some may refuse to recite the Pledge because they think it is "false," other reasons for refusal are legitimate. See, for example, Barnette, 319 US at 645 (Murphy concurring) ("To many it is deeply distasteful to join in a public chorus of affirmation of private belief."); and Lundquist, 278 A2d at 266, 274-75 (teacher refused because he believed that coerced Pledge recitation eliminated his right to freely express his own loyalty to the United States). The Court has frequently protected the individual's right not to reveal his beliefs even for the purpose of showing that compulsory speech or support contravenes those beliefs. See Abood, 431 US at 241; Cramp, 368 US at 285-88; and Sweezy, 354 US 235, 239 n 6 (1957).

11 'The students' interests in this regard are not irrelevant. Even if the state has no constitutional obligation to provide students with information or ideas, Pico, 457 US at 888 (Burger dissenting), students may have an interest in not being provided with false information or ideas. See also then-Justice Rehnquist's dissent, which acknowledges that the right to receive information may be protected, but that the removal of books from the school library was not a complete denial of access. Id at 912-13. Because the teacher Pledge requirement involves forced speech, correction of the information conveyed (that the teacher "believes" in the Pledge) presumably is not likely to occur.
} 
ployee's private interest that may counterbalance asserted state interests; rather, the state's actual interests may also favor freedom of speech.

An examination of compelled speech and loyalty oath cases indicates that the Pledge recitation requirement, compelling the teacher to "assert as true" an ideological view, involves a very severe infringement on her expressional interests, one that may be justified only on more "urgent" grounds than restrictions on affirmative speech. If the school's purpose in requiring teacher recitation is to use her as an ideological model, allowing her to disaffirm belief in the Pledge defeats the purpose. If, on the other hand, the school claims that it merely wishes to use the teacher as a voicebox, its interest in making her recite the Pledge (rather than adopting alternative methods, such as broadcast over an intercommunications system) is much weaker. In either case, as was suggested in the discussion of compelled speech cases, the teacher's ability to disaffirm does not necessarily prevent infringement of her First Amendment interests:

Consideration of loyalty oath and schoolhouse expression cases reveals that imposing this kind of requirement is likely to harm the state's purposes in other ways, as well. As an oath, the pledge is vague and may deter constitutionally protected activities. It may also rob the state of some of its most sincere employees and trivialize the commitment embodied in the Pledge itself. Finally, one could argue that the teacher's position is unique because of the Court's approval of her role as an ideological model; however, values of free inquiry, open-mindedness and tolerance-values already affirmed by the Court in a number of schoolhouse and academic freedom cases-suggest that the teacher, like most other public employees, may not be forced to affirm ideological beliefs.

Because this Comment has argued that forced Pledge recitation is unconstitutional as a compelled affirmation of belief, it suggests protection for teachers' free speech rights that is both narrower and broader than the language of the lower court opinions may imply. The protection is narrower in that the argument acknowledges state interests in controlling the schoolhouse expression of teachers that differ from those in controlling the expression of students. It is broader, though, in that it does not necessitate fact-based inquiries to determine when compelling a lie is the more expedient course. Instead, it provides the teacher, the student, and the community with the knowledge that when the role models who "shape the attitude of young minds" appear to affirm fundamental truths about America's political values, the affirmation, and that which is affirmed, is true. 